\section{Aims and Scope}

The Journal of Radiotherapy in Practice is a peer-reviewed journal covering all of the current modalities specific to clinical oncology and radiotherapy. The Journal aims to publish quality research from a wide range of styles and encourage debate and the exchange of information and opinion from within the field of radiotherapy practice and clinical oncology. The Journal also aims to encourage technical evaluations and case studies as well as equipment reviews that will be of interest to an international radiotherapy market.

The Journal of Radiotherapy in Practice aims to provide an easily available forum for education matters by publishing regular high-standard Continuing Professional Development articles.
The Journal of Radiotherapy in Practice will include research papers, scientific papers, technical articles, case studies and review articles relevant to anyone with an interest in clinical oncology and radiotherapy including: research; treatment planning; radiotherapy techniques/ protocols; portal imaging; continuing professional development; education and training; new technology; networking.

The Editor-in-Chief welcomes any suggestions to submission of manuscripts to the journal. Please refer to the online Instructions to Authors available at www.journals.cambridge.org/jrp. Please write to the Editor-in-Chief if you require further assistance in submitting an article for publication.

\section{Publisher}

Dan Edwards, Commissioning Editor, Cambridge University Press, Journals, University Printing House, Shaftesbury Road, Cambridge CB2 8BS, UK.

Tel: 44 (0)1223 326491

Fax: $44(0) 1223325802$

E-mail: dedwards@cambridge.org

\section{Subscriptions}

Journal of Radiotherapy in Practice is published annually in one Volume of four Issues in March, June, September and December. The subscription rate for 2013, Volume 12 is:

- Individual rate $£ 126$ or $\$ 241$

- Institutional rate $\mathcal{E}^{334}$ or $\$ 535$

Correspondence concerning subscriptions should be addressed to: Journals Customer Services, Cambridge University Press, Edinburgh Building, Cambridge CB2 8RU, UK.

Tel: +44 (0)1223 326070

Fax: +44 (0)1223 325150

E-mail: journals_subscriptions@cambridge.org

Web: www.cambridge.org; Cambridge Journals

Online: www.journals.cambridge.org.

\section{Advertising Sales}

Please contact Cambridge University Press, Advertising and Special Sales, Journals, University Printing House, Shaftesbury Road, Cambridge CB2 8BS, UK.

Tel: +44 (0)1223 325757

Fax: +44 (0)1223 325802

E-mail: ad_sales@cambridge.org

\section{Abstracting/Indexing}

The Journal of Radiotherapy in Practice is indexed and abstracted in EMBASE/Excerpta Medica.

\section{Copyright}

ISSN 1460-3969

(C) Cambridge University Press 2013. Apart from fair dealing for the purposes of research or private study, or criticism or reviews, as permitted under the Copy right, Designs and Patents Act, 1988, this publication may only be reproduced, stored or transmitted, in any form or by any means, with the prior permission in writing of the publishers (Cambridge University Press, Edinburgh Building, Shaftesbury Road, Cambridge, CB2 8RU, UK), or in the case of reprographic reproduction in accordance with the terms of licences issued by the Copyright Licensing Agency, 90 Tottenham Court Road, London WIP 9HE, UK.

Notes to users in USA. Authorisation to photocopy items for internal or personal use is granted by Cambridge University Press provided that the appropriate fees are paid directly to the Copyright Clearance Center, 222 Rosewood Drive, Danvers, MA 01923, USA. For more information please contact CCC. For territories outside North America, permission should be sought direct from the copyright holder. This consent does not extend to other kinds of copying, such as copying for general distribution, for advertising and promotional purposes, for creating new collective works, or for resale.

Typeset by MPS Limited, Bangalore, India. Printed in Great Britain by Bell \& Bain.

This journal issue has been printed on FSC-certified paper and cover board. FSC is an independent, non-governmental, not-for-profit organization established to promote the responsible management of the world's forests. Please see www.fsc.org for information. 
JOURNAL OF

\section{RADIOTHERAPY IN PRACTICE}

\section{CONTENTS}

In this issue

\section{ORIGINAL ARTICLES}

Palliative radiotherapy for bone metastases: assessment of factors influencing dose-fractionation schedules at a UK cancer centre

N. Bhalla, H. Wong, A. Ibrahim, J. A. Green

A prospective study of patients with impending spinal cord compression treated with palliative radiotherapy alone

L. O'Sullivan, A. Clayton-Lea, O. McArdle, M. McGarry, J. Kenny, M. Dunne, E. O'Shea, C. Small, M. Moriarty, P. Thirion

The dosimetric impact of supplementing pre-planned prostate implants with discretionary ${ }^{125}$ I seeds

Neil McParland, Nicholas Chng, Mira Keyes

Radiation therapist perspectives on cone-beam computed tomography practices and response to information

Caitlin Gillan, Winnie Li, Nicole Harnett

Radiographers relationship with head and neck cancer patients

Helen Egestad

LITERATURE REVIEW

A review of vascular disrupting agents as a concomitant anti-tumour modality with radiation

William Tyler Tran, Ahmed El Kaffas, Azza Al-Mahrouki, Carol Gillies, Gregory Jan Czarnota

\section{SHORT COMMUNICATION}

Image-guided radiation therapy for carcinoma of gallbladder: implication on margin for set-up errors

Gagan Saini, Vineeta Goel, Anil K Anand, Kamlesh Kumar Gupta

\section{TECHNICAL NOTE}

Development and evaluation of a Perspex anthropomorphic head and neck phantom for three dimensional conformal radiation therapy (3D-CRT)

Khaldoon M. Radaideh, Laila M. Matalqah, A. A. Tajuddin, W. I. Fabian Lee, S. Bauk, E. M. Eid Abdel Munem

LETTER TO EDITOR

Recording a patient diet over the radical course of radiotherapy for prostate cancer using a diet diary: a feasibility study

Helen A McNair, Linda Wedlake, Clare Shaw, Jervoise Andreyev, David Dearnaley

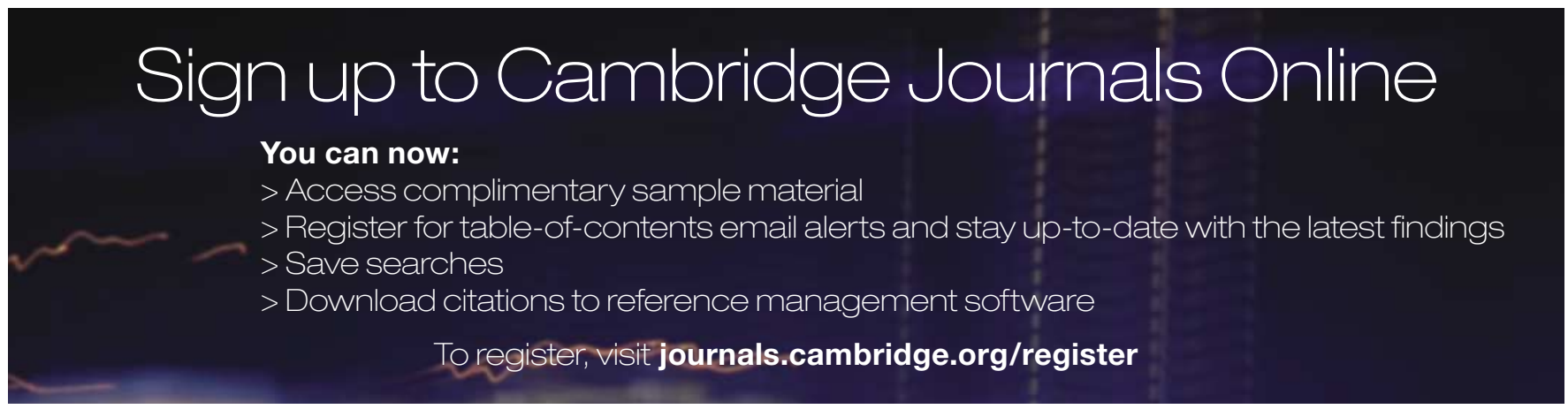

